Article

\title{
Improving Occupant Wellness in Commercial Office Buildings through Energy Conservation Retrofits
}

\section{J. J. McArthur ${ }^{1, *}$, Chris Jofeh ${ }^{2}$ and Ann-Marie Aguilar ${ }^{3}$}

1 Department of Architectural Science, Ryerson University, 350 Victoria Street, Toronto, ON M5B 2K3, Canada

2 Arup, 4 Pierhead Street, Cardiff CF10 4QP, UK; E-Mail: chris.jofeh@arup.com

3 Arup Associates, 8 Fitzroy Street, London W1T 4BJ, UK;

E-Mail: ann-marie.aguilar@arupassociates.com

* Author to whom correspondence should be addressed; E-Mail: jjmcarthur@ryerson.ca; Tel.: +1-416-979-5000 (ext. 4082); Fax: +1-416-979-5353.

Academic Editor: Derek Clements-Croome

Received: 5 September 2015 / Accepted: 1 October 2015 / Published: 21 October 2015

\begin{abstract}
There is increasing literature demonstrating the link between building indoor environmental quality, and occupant health and productivity, driving the corporate real estate industry to investigate how to integrate wellness features in both new and existing building stock. Meanwhile, new voluntary standards to promote occupant health are becoming adopted alongside sustainability standards. As commercial building owners and tenants seek to improve occupant conditions and incorporate wellness, apparently conflicting priorities must be balanced, particularly improving indoor environmental conditions has the potential to increase energy. This paper presents a framework to consider retrofits holistically and considering the benefit of improved conditions both qualitatively and quantitatively. Where poor conditions exist, published literature demonstrates a lost productivity cost that exceeds typical building energy costs, and this is quantified in the financial analysis presented. Energy retrofits provide a unique opportunity to integrate wellness-enabling features because the energy savings can offset marginal energy or operating cost increases for particular wellness interventions. This paper presents a flexible, customizable framework to develop potential retrofit bundles and evaluate them considering economic, sustainability, wellness, risk and occupant experience factors to identify the optimal zone of retrofit. An illustrative case study using real building data demonstrates how the framework might be applied to a real project and customized to achieve unique stakeholder priorities.
\end{abstract}


Keywords: occupant wellness; building retrofit; energy conservation; sustainability; occupant health; productivity

\section{Introduction}

Wellness and productivity are significant considerations for businesses, as staff costs typically make up $50 \%-85 \%$ of the budget $[1,2]$. When office conditions (poor indoor air quality, thermal discomfort, poor lighting, etc.) negatively affect productivity or employee health, the economic impact for the company is significant $[2,3]$. While energy costs (either paid directly or indirectly) represent a small fraction of the total cost of doing business for the average occupant, wellness features can have a much larger impact; consequently, there is increasing discussion in the Corporate Real Estate (CRE) industry on how to improve occupant health and wellness. A recently published standard that is receiving substantial industry attention and has been adopted by several Green Building Councils (e.g., ref. [4] is the WELL ${ }^{\circledR}$ Building Standard [5], which was created to allow certification of buildings designed and operated to promote occupant wellness. This paper is not intended to evaluate the effectiveness of this standard in promoting wellness, but uses it as a conceptual framework to evaluate factors known to affect wellness within a larger context.

Concurrently, market demand for high building energy performance is driving increased investment to achieve higher building energy ratings by Real Estate Investment Trusts (REITs) [6] and increasing adoption of sustainable certifications in the larger CRE community [7-9]. Because energy retrofits are commonly occurring in buildings, this provides an opportunity for incorporation of wellness enablers. This paper discusses the holistic benefits of such retrofits and presents a framework to evaluate potential approaches ("retrofit bundles") that considers wellness impact and energy efficiency, as well as commercial/financial implications, risk management, and occupant satisfaction (qualitative) issues, within a commercial real estate context. A sample case study using real building data is provided to demonstrate the use of this framework as a decision-making tool.

\section{Wellness and Energy Efficiency in the Building Context}

Current benchmarking and available data have shown that as the market for sustainable buildings is growing globally [10], the Commercial Real Estate (CRE) industry is embracing investment in this area [11]. As Environmental Product Certificates for buildings (i.e., building energy labels) become adopted increasingly internationally [10,12-14], Both large empirical industry studies $[15,16]$ and academic research have found that high sustainability certification ratings lead to statistically significant decreases in vacancy rates $(10 \%)$ and increases to property value (10\%-25\%) [17-19]. A comprehensive review [19] of academic papers and industry surveys demonstrated both increased rental rates for sustainable and energy-efficient properties and a willingness by the majority (70\%) of tenants to pay a premium to occupy such properties. In similar research, poor energy performance has correlated with reduced rental rates [20,21], reinforcing the commercial importance of energy performance.

Energy conservation measures (ECMs) reduce energy consumption and thus directly impact the operational costs of a building, motivating the party responsible for paying utility bills to invest in ECMs 
providing an acceptable payback period. Incentives further improve the financial attractiveness of these measures, either in the form of a cash rebate, reduced development charges or building permitting fees, or decreased tax burden. Regulatory pressures such as Mandatory Building Energy Labelling [22], along with local legislation - both incentives and carbon taxes-provide additional motivation for these improvements [1]. Indirect benefits of the ECMs also result in economic benefit to the owners, such as Green Premium rental rates and increased absorption and lower vacancy rates due to tenant retention and attraction to more sustainable buildings [16,19]. Conversely, poor performance has been correlated with tenant relocation from the property [22].

This combination of factors can be used to support a strong financial case for landlords to improve the energy efficiency of their buildings, although research has shown that this can be complicated where a split incentive exists [23]. Landlords charging on a gross rent basis avoid the split incentive dilemma as they will benefit directly from decreased operating costs (and thus increased net operating income (NOI)) from any energy savings. Conversely, when they charge on a net rent basis, the tenants pay their own utilities and thus there is no direct financial benefit to the landlord. That said, it has been demonstrated $[12,17,18,20]$ that lower occupancy costs due to low utility rates attract and help retain tenants and in many instances simultaneously allow a Green Premium rents to be charged, providing an identifiable, albeit indirect, payback.

From a tenant perspective, if paying their own utility rates and given an adequately long lease (i.e., exceeding the payback period), several fit-out ECMs are financially viable, and the scope of these increases in instances where the landlord shares the burden of investment. Those tenants paying Gross Rents, however, have difficulty justifying investment in ECMs, unless these are inherent in renovations and retrofits addressing wellness and thus improving employee productivity and satisfaction [24].

After the 1970s oil crisis and the rise in energy conservation retrofits, "Sick Building Syndrome" prevalence began to rise, with fully air-conditioned buildings most typically affected [25]. Recent research has identified increased productivity with increased ventilation rates. For example, Wargocki et al. [26] correlated performance improvements of $1.7 \%$ for each doubling of ventilation rate for tasks simulating "normal office work". Indoor air pollution is known to negatively affect cognitive function, overall health and absenteeism [2,3,15,25-27], while daylighting has been correlated with improved performance [28] in school due to improved visibility due to higher illumination levels and better light quality, mental stimulation, and improved mood, behavior or well-being. In the healthcare context, studies have shown that access to daylighting where the patients have control over the lighting levels and blinds result in improved patient outcomes and more rapid recovery [29]. Given the impact of the building environment on health and productivity, neither occupants nor landlords can afford to overlook the factors affecting occupant wellness in buildings when planning investment in buildings. Where occupants are aware of these factors, e.g., where post-occupancy or employee health studies have been undertaken, they are often primary drivers in the decision to either (a) remain in the building, (b) vacate, or (c) remain only if remediation work is done.

Significant research has been undertaken within the healthcare/hospital context in the United Kingdom to identify best practices for wellness in buildings. The National Health Service in the UK developed a progression of Toolkits [30,31] to evaluate and guide hospital design to facilitate improved working environments for staff and a better therapeutic environment for patients. The key factors rated within the staff and patient environment section of this guide include views, access to outdoors, thermal 
comfort, thermal system controllability, attractiveness of building, understandable building navigation, good sanitation facilities for patients, and good relaxation spaces for staff. A complementary report [32] looked at the recruitment, retention and performance of nurses in the same context, and how this is impacted by elements of the building itself and the hospital design. This report found that the quality of external space and the internal environment were the two most important factors in nurse retention, above space functionality, staff facilities and civic value. Within these two areas, the most important factors raised (which could be affected by a retrofit) were access to sufficient parking, public spaces fostering interaction and controllability of the environment (i.e., temperature control). Some survey respondents even indicated that "the ability to control the local environment in which they worked could have an impact on the sickness levels of staff".

The discussion of wellness and building design does not simply apply to hospitals. Post-occupancy evaluation and occupant satisfaction studies are widely used in a variety of commercial, institutional, residential and industrial buildings, and are often the only way for a building owner or occupant to understand what may be driving reduced productivity. The Building Use Studies methodology [33] was the original method to evaluate occupant satisfaction, beginning in the 1990s. Because it has been in long-term use, it is possible to benchmark levels of occupant satisfaction against a large database of results for similar buildings. This methodology is summarized in twelve indicators to summarize the overall building performance: summer temperature, winter temperature, summer air quality, winter air quality, lighting, noise, comfort, design, needs, health, image to visitors, and perceived productivity, the latter of which most clearly demonstrates the economic benefits of wellness in buildings.

\section{Framework Development Methodology}

The proposed framework is based on procedures initially developed in 2008 to support building retrofit consulting projects, and subsequently refined over approximately 20 projects globally to adapt to changing market drivers and lessons learned through these projects, particularly in the commercial office context. Table 1 indicates the chronology of this development process. There are five steps in the proposed methodology: (i) priority identification; (ii) renovation bundle development; (iii) quantitative analysis; (iv) qualitative analysis; and (v) bundle evaluation.

Table 1. Framework development.

\begin{tabular}{|c|c|}
\hline Year & Tool Development Milestones \\
\hline 2008 & $\begin{array}{l}\text { BEEFIT tool developed by Arup to help identify best approach for renovation of } 1200 \text { buildings; } \\
\text { incorporated detailed qualitative and quantitative analysis }\end{array}$ \\
\hline 2010 & $\begin{array}{l}\text { AssetMAP tool developed by Arup based on BEEFIT and refined based on extensive industry } \\
\text { consultation to help identify quickly and without wasted effort the best strategic direction for the } \\
\text { upgrade of a building adapted to the UK context }\end{array}$ \\
\hline 2011 & AssetMAP portfolio analysis pilot project (London, UK) \\
\hline 2012 & AssetMAP revised to adapt to the North American context \\
\hline 2013 & AssetMAP tool extended to integrate CRE market analysis, valuation impact, and risk \\
\hline 2014 & Extended AssetMAP tool refined based on pilot study results \\
\hline 2015 & WELL ${ }^{\circledR}$ Building Standard key concepts incorporated in assessment framework \\
\hline
\end{tabular}




\subsection{Stakeholder Priority Identification}

In order to properly focus the renovation efforts to achieve the most significant outcomes, a multi-variant analysis approach (similar to [34], for example) is used. Five types of performance are considered in this analysis: (1) financial performance (Net Present Value); (2) environmental performance (ekWh/year or GHG emissions); (3) alignment with known wellness enablers; (4) qualitative factors affecting occupant experience; and (5) risk mitigation.

Rarely, if ever, does one bundle consistently out-perform the others in all categories. Instead, the performance in each category must be considered in accordance with the priorities and situation of the stakeholders. A series of discussions with the client allows these to be determined; first, client needs and priorities are collected by the team and initial weightings for cost $\left(W_{C}\right)$, greenhouse gas emissions $\left(W_{G H G}\right)$, qualitative factors $\left(W_{Q}\right)$, risk mitigation $\left(W_{R}\right)$, and wellness $\left(W_{W}\right)$, such that these priorities sum to 1 . For individual stakeholders, the initial values are estimated based on this initial charette and presented back to the stakeholder for confirmation or correction. This makes use of expert judgment while also ensuring that the resultant weighting factors truly represent the stakeholder priorities. Where multiple stakeholders are involved, this process is complex strategies such as agent-based modeling [35] must be used. It is critical that these factors be determined at the beginning of the process to avoid bias of a preferred renovation bundle during the final evaluation. To calculate the overall bundle scores, the performance of each bundle is normalized compared with the best bundle's performance and then multiplied by the category weighting factor, each multiplied by a factor to normalize the bundle's performance compared with the best-performing bundle category as indicated in Equation (1):

$$
X_{T O T_{i}}=W_{C} \times \frac{\Delta N P V_{i}}{\Delta N P V_{\max }}+W_{G H G} \times \frac{G H G_{\min }}{G H G_{i}}+W_{Q} \times \frac{Q_{i}}{Q_{\max }}+W_{R} \times \frac{R_{i}}{R_{\max }}+W_{W} \times \frac{W_{i}}{W_{\max }}
$$

where the subscript $i$ refers to the performance of bundle $i$ and the subscripts max and min refer to the highest and lowest bundle scores (representing best performance for different categories), $X_{\text {TOT }}$ is the bundle holistic performance, $\triangle N P V$ is the incremental net present value (over the selected period) for the bundle compared with the baseline case, GHG is the annual operating greenhouse gas emissions associated with the bundle (note that the minimum value is the best-performing for this category only), $Q$ is the qualitative performance, $R$ is the risk mitigation performance, $W$ is the wellness performance, and $W_{C}, W_{G H G}, W_{Q}, W_{R}$, and $W_{W}$ are the weighting factors defined previously.

Where a single stakeholder is involved, the individual priorities and relative importance of each factor are discussed at an initial charette, weighting factors developed based on the input received and assigned priority weightings reviewed to confirm that the bundle evaluation metric has been appropriately tailored to stakeholder priorities. Where multiple stakeholders are involved (for example, both the landlord and tenant are investing in a building renovation), the use of multi-agent decision-making strategies are required. In these instances, the reader is encouraged to refer to $[35,36]$ for methods to develop appropriate weighting factors reflecting the diversity of stakeholder priorities, as well as to [24] for a broader discussion of temporal value interactions in such projects.

For the three qualitative types of factors (wellness, qualitative, and risk mitigation), specific drivers can be further defined in discussions with stakeholder(s) to further tailor the analysis to prioritize particular issues. For example, wellness drivers may be selected from the WELL standard [5] if 
certification is a priority, or simply as a guideline for incorporating wellness, and could include increased individual thermal comfort control, maximizing views of the outdoors, or reducing ambient noise. Qualitative drivers are elements that are difficult to quantify and might include the adaptability of the new space, sustainability certification level, or the desire to increase the prestige of the occupant's brand through the renovation. Finally, risk mitigation drivers might include improving energy security and resilience through on-site generation, reduced exposure to carbon tax liabilities, or reducing the risk of obsolescence of older buildings. Each selected driver is assigned a driver priority factor $\left(W_{p}\right)$ ranging from 0.1 (low) to 1.0 (high), again based on stakeholder feedback, to inform the qualitative assessment presented later in this paper.

\subsection{Renovation Bundle Development}

A "baseline" renovation bundle is developed to reflect the minimum investment required for re-leasing of space. Capital expenses (CapEx) are limited to the replacement of end-of-life equipment, repair of damaged building finishes, cladding and systems, and an area-based allowance for new fit-out. Energy savings are limited to the savings achieved by a replacement of the end-of-life equipment with equal level of efficiency (i.e., if equipment was standard efficiency, it will be replaced with current standard efficiency equipment, etc.). Operating expenses (OpEx) are typically expected to stay the same, except that maintenance costs are updated to reflect equipment replacement or continued deferral, using best engineering judgment. Rental rates and the cap rate are adjusted for inflation and market dynamics only and must be informed exogenously using current market data relevant to the building(s) under consideration.

A series of additional bundles are then developed conceptually by the design team, considering a range of ECMs, wellness enablers and other drivers identified in Section 3.1. Each bundle is designed to address one or more of: commercial attractiveness (cosmetic/amenity renovations), technical performance, and wellness, and range from a low-hanging fruit approach (no-cost/low-cost interventions) to exemplar upgrades designed to meet the highest standards.

\section{Model Derivation and Retrofit Analysis Calculations}

A framework for retrofit evaluation has been previously published [37] to allow the evaluation of potential renovation bundles $(i=1,2,3$, etc.) to be evaluated based on financial performance, environmental performance, qualitative occupant experience, and risk mitigation. This paper proposes an expansion to this model to include wellness enablers, which affects the treatment of financial performance and adds a wellness indicator. This model is not re-presented in its entirety and the reader is encouraged to consult the original work for the environmental impact $\left(G H G_{i}\right)$, qualitative $\left(Q_{i}\right)$, and risk $\left(R_{i}\right)$ evaluations.

\subsection{Financial Evaluation of Bundles}

In order to undertake a comparative quantitative analysis, both the current building performance as well as the estimated capital costs and durations, operational expenses /savings, and potential market impact (rent uplift, impact on vacancy rate, cap rate and/or property value, and vacancy period during construction) must be developed exogenously for each bundle, using energy modeling software, cost 
estimates and historical maintenance data. Because wellness enablers in office buildings has been tied to improved (or reduction in decreased) productivity, there is an economic value to the occupants to improving the indoor conditions in a building, most notably indoor air quality and lighting [2,3,25-30,36]. As a result, in buildings where there is evidence of poor conditions, a productivity benefit may be included in these calculations. This expands the previously published relationship [38] with the fourth term, as presented in Equation (2):

$$
\Delta N P V_{i}=\Delta P_{i}+\frac{\Delta O P_{\text {no_rent }_{i}} \times \mathrm{i}_{\mathrm{d}}}{\left[1-\left(1+\mathrm{i}_{\mathrm{d}}\right)\right]^{\mathrm{N}_{\mathrm{t}}}}+\frac{\Delta I_{\text {rent }_{i}} \times \mathrm{i}_{\mathrm{d}}}{\left[1-\left(1+\mathrm{i}_{\mathrm{d}}\right)\right]^{\mathrm{N}_{\mathrm{t}}}}-\frac{\Delta I_{\text {rent }_{i}} \times \mathrm{i}_{\mathrm{d}}}{\left[1-\left(1+\mathrm{i}_{\mathrm{d}}\right)\right]^{\Delta D_{i}}}+\frac{\Delta I_{\text {prod }_{i}} \times \mathrm{i}_{\mathrm{d}}}{\left[1-\left(1+\mathrm{i}_{\mathrm{d}}\right)\right]^{\Delta D_{i}}}
$$

In this equation, the incremental net present value of the bundle under consideration, $i$ is calculated compared with a baseline case. $\Delta P_{i}$ represents the incremental present cost for each renovation bundle over the baseline, $\triangle O P_{i}$ represents the incremental operating cost, $\Delta I_{\text {rent }}$ reflects the rental uplift, $i_{d}$ represents the discount rate, $N_{t}$ represents the number of rental periods under consideration, and $\Delta D_{i}$ represents the number of rental periods until rental income is received post-renovation. The fifth term reflects the financial benefit of remediating known issues affecting productivity. There has been significant research relating building conditions and productivity (key findings summarized in Table 2) where productivity (measured within its context) in the presence of wellness enablers (e.g., daylighting, fresh air) is compared with productivity in poor conditions and significant impacts have been found. Very little research compares productivity improvements from the betterment of favorable conditions (i.e., the presence of enablers) and thus this term should only be included for remedial interventions. The context of each study is also important, as the nature of "productivity" changes across building types. Most of the cited studies are from offices and schools, and thus relate best to the context of the "white collar" or knowledge-based work environment. Studies related to other contexts have been cited to demonstrate a consistency of results across sectors, not to encourage the use of such data out of context.

Within the office context, however, a high percentage of business costs are spent on salaries [1], resulting in a high financial benefit to organizations who can improve the productivity of their staff. Where conditions are known to affect productivity, a here $\Delta I_{\text {prod }}$ is defined as a function of the total salary cost, $C_{\text {sal }}$, times the percentage positive effect on productivity from the published literature ( $R_{\text {prod; }}$ refer Table 3 ) for the bundle, and a scaling factor, $S F_{\text {prod, }}$ ranging from zero (satisfactory conditions) to one (extremely poor conditions; untenable conditions, and evidence of sick building syndrome), as shown in Equation (3):

$$
\Delta I_{\text {prod }}=C_{\text {sal }} \times \sum R_{\text {prod }} \times S F_{\text {prod }}
$$

The use of a zero scaling factor for satisfactory conditions arose because context of the research presented in Table 3 is most often comparing poor conditions (e.g., "low levels of daylight") with improved conditions. The productivity impact of conditions improved from a satisfactory state is not clearly presented in the literature and thus the $\Delta I_{\text {prod }}$ term is included only for remedial interventions. Note also that for landlord/non-occupant investors, this productivity benefit would be realized only indirectly and is best considered as a risk reduction (i.e., tenant retention) strategy, rather than an ongoing cost savings. 
Table 2. Potential drivers and priorities to guide renovation bundle development.

\begin{tabular}{|c|c|c|c|}
\hline Element & Impact on Productivity * & Context & Reference \\
\hline Outdoor Air & $\begin{array}{l}\mathbf{1 . 7 5 \%} \text { increase on office worker productivity per } \\
\text { doubling of outdoor air rate }\end{array}$ & $\begin{array}{l}\text { Commercial } \\
\text { office }\end{array}$ & {$[26]$} \\
\hline $\begin{array}{l}\text { Indoor Air } \\
\text { Quality }\end{array}$ & $\begin{array}{l}\text { 6\%-9\% decreased productivity in poor indoor air } \\
\text { quality environments }\end{array}$ & $\begin{array}{l}\text { Commercial } \\
\text { office }\end{array}$ & {$[3]$} \\
\hline \multirow{3}{*}{ Daylighting } & $\begin{array}{c}\text { Learning progress showed } \mathbf{7 \%} \text { to } 26 \% \text { improvement in } \\
\text { highly daylit rooms compared with low levels of } \\
\text { daylight }\end{array}$ & Schools & {$[28]$} \\
\hline & $\begin{array}{l}\text { Learning progress showed } 19 \%-20 \% \text { improvement } \\
\text { when skylight providing additional access to daylight } \\
\text { compared with non-daylit rooms }\end{array}$ & Schools & {$[28]$} \\
\hline & $\begin{array}{l}\text { Average length of stay (hospitalization) decreased from } \\
\qquad 16 \% \text { to } 41 \% \text { in highly-daylit rooms }\end{array}$ & $\begin{array}{l}\text { Hospitals } \\
\text { (patients) }\end{array}$ & {$[29]$} \\
\hline Access to views & $\begin{array}{l}\text { Learning progress showed } \mathbf{1 5 \%} \text { to } 23 \% \text { improvement in } \\
\text { classrooms with largest windows }\end{array}$ & Schools & {$[28]$} \\
\hline $\begin{array}{l}\text { Openable } \\
\text { windows }\end{array}$ & $\begin{array}{c}\text { Ranges from } 7 \% \text { to } 8 \% \text { improvement in classrooms with } \\
\text { operable } v \text { s. not operable windows }\end{array}$ & Schools & {$[28]$} \\
\hline $\begin{array}{l}\text { Illumination } \\
\text { level control }\end{array}$ & $\begin{array}{l}\text { 4.5\% increase in productivity at workstations with } \\
\text { lighting control }\end{array}$ & Manufacturing & {$[38]$} \\
\hline
\end{tabular}

Notes: * recommended $R_{\text {prod }}$ values are shown in bold text.

\subsection{Wellness Evaluation of Bundles}

The WELL ${ }^{\circledR}$ Building Standard [5], standard evaluates an environment's compliance with 102 factors across seven concepts: air, water, noise, nourishment, light, fitness, comfort, and mind to eliminate "keystone hazards" that can significantly undermine our health. While it is possible to evaluate each bundle based on each of the 102 features listed, this model proposes a simplification, whereby those elements that are affected primarily by the renovation construction (as opposed to post-occupancy operations) are considered. Table 3 presents a summary of the wellness credits and prerequisites in the WELL $^{\circledR}$ Building Standard, indicated by number (per [5]). Those with a potential impact on energy consumption are indicated in bold text while those that are pre-conditions for tenant improvement (i.e., renovation) certification are underlined). For each, complementary energy conservation measures that align with, or are affected by the achievement of the credit is identified, and their relative impact on building energy consumption for each enabler is described. Note that the latter will vary by climate zone, occupancy and building construction and as such cannot be summarized as a percentage increase or decrease in energy.

As described in Section 3.1, the subset of wellness drivers for evaluation has been identified and assigned a priority factor during the kick-off charette. The wellness-enabling potential of a renovation bundle is included by adding a wellness benefit term to the model as shown in Equation (4), where $W_{p}$ is the concept priority and $C_{W}$ indicates the performance of a bundle with regard to this wellness concept. These can be further broken down into features where there are strong stakeholder requirements for this level of granularity. 


$$
W_{i}=\frac{\sum_{w=1}^{N_{W}}\left(W_{p_{w}} \times C_{W_{w}}\right)}{N_{w}}
$$

Note that this is the same approach used for qualitative $\left(Q_{i}\right)$ and risk factor $\left(R_{i}\right)$ evaluation, as previously indicated in [37].

Table 3. WELL ${ }^{\circledR}$ Building Standard elements affected primarily by construction decisions, complementary energy conservation measures (ECMs) and effect on energy consumption.

\begin{tabular}{|c|c|c|}
\hline \multicolumn{2}{|r|}{ Wellness Concepts * } & Complementary Renovation Elements and Influence on Energy Use \\
\hline \multirow{4}{*}{ 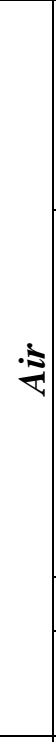 } & $\begin{array}{l}\text { Air Quality- } \\
\text { Contaminants }(\underline{01}, \underline{04}, \underline{\mathbf{0 6}}, \\
08, \underline{11}, \mathbf{1 4}, 24,25,26,27 \\
\text { 28) }\end{array}$ & $\begin{array}{l}\text { These items generally affects selection of materials } \\
\text { 06: requires UV lights in air handling units (negligible energy use) } \\
\text { 14: requires vestibules (energy decreases if not present) }\end{array}$ \\
\hline & $\begin{array}{c}\text { Increased ventilation }(\underline{03}, \\
15,19,20,21)\end{array}$ & $\begin{array}{l}\text { 03: Compliance with ASHRAE } 62.1 \text { and balancing are best practice; } \\
\text { demand-controlled ventilation somewhat reduces energy use ** } \\
\text { 15: Increasing outdoor air by } 30 \% \text { above ASHRAE } 62.1-2013 \text { increases air } \\
\text { tempering load. } \\
\text { 19: Allows natural ventilation (reduced fan energy and free cooling) during } \\
\text { shoulder season, decreasing energy use } \\
20 \& 21 \text { : biases HVAC design to more efficient systems }\end{array}$ \\
\hline & Air filtration $(\underline{\mathbf{0 5}}, \mathbf{2 3})$ & Increase external static pressure in airstream, increasing fan energy \\
\hline & $\begin{array}{l}\text { Moisture and humidity } \\
\qquad(\mathbf{1 2}, \mathbf{1 6})\end{array}$ & $\begin{array}{l}\text { These affect HVAC system criteria but are typical values } \\
\text { (ASHRAE, 2013) }\end{array}$ \\
\hline $\begin{array}{c}\bar{z} \\
\bar{z} \\
\vdots \\
\vdots\end{array}$ & $\begin{array}{l}\text { Drinking Water } \\
\text { Promotion (37) }\end{array}$ & $\begin{array}{l}\text { 37: Installation of additional water stations and treatment facilities may } \\
\text { complement installation of reduced-flow fixtures }\end{array}$ \\
\hline \multirow{2}{*}{ 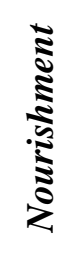 } & $\begin{array}{l}\text { Food production and } \\
\text { storage }(\underline{42}, \mathbf{5 0}, \mathbf{5 1})\end{array}$ & $\begin{array}{l}42 \text { and 51: Refrigerator quantity (plug load) may increase } \\
\text { 50: Green (garden) roof installation provides opportunity for roof } \\
\text { insulation upgrade, decreasing envelope loads }\end{array}$ \\
\hline & Eating/Break Area (52) & Impacts architectural program and space use \\
\hline \multirow{2}{*}{$\stackrel{\mathscr{\Xi}}{:}$} & $\begin{array}{l}\text { Interior fitness circulation } \\
\text { (64) and active } \\
\text { furnishings (71) }\end{array}$ & $\begin{array}{c}\text { Reduced elevator energy use; may complement natural ventilation and } \\
\text { daylight strategies (e.g., atria). Active workstations slightly increase plug } \\
\text { loads. }\end{array}$ \\
\hline & $\begin{array}{l}\text { Exterior active design } \\
\text { (67); active transportation } \\
\text { support (69) }\end{array}$ & $\begin{array}{l}\text { 67: Promotes green space and seasonal shading strategies } \\
\text { 69: Promotes inclusion of bicycle storage and additional showers (hot } \\
\text { water heating energy and total water increase) }\end{array}$ \\
\hline \multirow{3}{*}{ 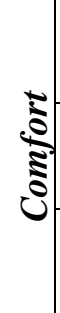 } & $\begin{array}{l}\text { Acoustic }(74, \underline{75}, 78,79 \\
80,81)\end{array}$ & $\begin{array}{l}\text { All guide design to account for acoustics; new silencers/attenuators may } \\
\text { increase fan energy for existing systems. }\end{array}$ \\
\hline & Thermal control (82) & $\begin{array}{l}\text { Perceived comfort is higher with less heating and cooling and can reduce } \\
\text { heating and cooling loads; complements building controls upgrades }\end{array}$ \\
\hline & Thermal comfort $(\underline{76}, 83)$ & $\begin{array}{l}\text { 76: ASHRAE 55-2013 is typical best practice (no effect on energy) } \\
\text { 83: Radiant systems typically reduce fan energy compared with VAV }\end{array}$ \\
\hline
\end{tabular}


Table 3. cont.

\begin{tabular}{l|l|l}
\hline \multicolumn{2}{|c|}{ Wellness Concepts * } & \multicolumn{1}{|c}{ Complementary Renovation Elements and Influence on Energy Use } \\
\hline & Design $(\underline{87}, 99)$ & These promote design aesthetics and influence architectural design \\
\cline { 2 - 3 } & Biophilia $(\underline{88}, 100)$ & $\begin{array}{l}\text { Biophilic design principles inform environmental elements, lighting and } \\
\text { space layout as well as internal/external green spaces; indoor water feature } \\
\text { may increase cooling/dehumidification load in hot/humid climates. }\end{array}$ \\
\hline
\end{tabular}

Notes: * numerals indicate credit numbers, those in bold text have a potential impact on energy consumption and underlined text indicates a pre-condition for tenant improvement (i.e., renovation) certification; ** indicates elements where the extent of energy impact varies highly with the climate zone.

\section{Demonstration: Application of the Framework}

This section presents the proposed framework applied to a historical project delivered using the previously published methodology ([37], summarized below) to demonstrate how wellness evaluation would affect the decision-making process for a variety of weighting factors. This presentation of the project differs from the real-life case because wellness and qualitative factors had been considered as a single category, rather than separated. All data presented is based on the initial analysis; the difference in application is the sub-categorization of these factors, and the exploration of the impact of different factors as demonstrated in the demonstration project (Section 5). Note also that the intent of this section is to demonstrate the application of the framework and subsequent evaluation, not to comprehensively evaluate its effectiveness. Future research will undertake additional case studies to achieve the latter.

\subsection{Building Context and Stakeholder Priorities}

The project under consideration was a low-rise, $3300 \mathrm{~m}^{2}$ commercial office building in North America seeking to attract new tenants. The stakeholders involved in the analysis were the property owner and the asset management firm acting on their behalf. Because the goal of the retrofit was to attract new tenants, their needs were based on the asset manager's experience with comparable buildings in the immediate area, and current market demands and leasing trends. These were reflected in the following priorities: Demand for high energy performance (reflected in a "green premium" included in the rent for buildings where applicable), a high degree of thermal comfort, moderate concerns regarding acoustic comfort, and the desire for daylighting.

\subsection{Methodology}

The first step in this process was a kick-off charette where the stakeholder priorities were collected through a semi-structured interview regarding known building conditions, market demands, prospective tenant profile and associated needs, risk appetite of the owner, minimum acceptable financial performance, and sustainability/energy performance goals. This discussion allowed the weighting factors for each category (financial, environmental, risk, wellness, and qualitative performance) to be assigned, and individual wellness, qualitative, and risk drivers factors to be categorized and assigned a priority factor $\left(W_{p}\right)$. These priority factors as well as the overall category weighting factors were presented to the stakeholders after this charette and agreed to be appropriate and thereby formed the basis of the bundle development. 
Four bundles were developed based on a site walk-through to evaluate the existing conditions of the building, including equipment requiring replacement and damages, and represented significant increases in the scope of the renovation. These bundles are summarized in Table 4.

Table 4. Summary of renovation bundles.

\begin{tabular}{|c|c|c|c|c|c|}
\hline Factor & Baseline & Bundle 1 & Bundle 2 & Bundle 3 & Bundle 4 \\
\hline ECMs & \begin{tabular}{c|} 
RTU \\
replacement \\
with \\
standard \\
efficiency
\end{tabular} & $\begin{array}{l}\text { Baseline, } \\
\text { plus lighting } \\
\text { upgrade; } \\
\text { low-flow } \\
\text { fixtures }\end{array}$ & $\begin{array}{l}\text { RTU replacement } \\
\text { with } \\
\text { high-efficiency } \\
\text { air-source heat } \\
\text { pumps; lighting } \\
\text { upgrade; low-flow } \\
\text { fixtures }\end{array}$ & $\begin{array}{c}\text { Bundle } 1 \text { plus: gas } \\
\text { boilers; domestic hot } \\
\text { water heater changed } \\
\text { to gas-fired; VAV } \\
\text { units provided with } \\
\text { gas reheat to replace } \\
\text { baseboards } \\
\end{array}$ & $\begin{array}{c}\text { Bundle 3, plus } \\
10 \mathrm{~kW} \\
\text { roof-mounted } \\
\text { photovoltaic } \\
\text { array }\end{array}$ \\
\hline $\begin{array}{l}\text { Qualitative/Occupant } \\
\text { Experience Elements }\end{array}$ & $\begin{array}{c}\text { Demolition } \\
\text { of previous } \\
\text { layout, } \\
\text { Worn } \\
\text { finishes } \\
\text { replaced }\end{array}$ & $\begin{array}{l}\text { Same as } \\
\text { baseline }\end{array}$ & Same as baseline & $\begin{array}{l}\text { Lobby and } \\
\text { washroom } \\
\text { renovations; } \\
\text { upgraded ground } \\
\text { floor tiles }\end{array}$ & $\begin{array}{l}\text { Same as } \\
\text { bundle } 3\end{array}$ \\
\hline $\begin{array}{l}\text { Wellness-enabling } \\
\text { elements }\end{array}$ & $\begin{array}{l}\text { Replacement } \\
\text { of worn } \\
\text { finishes } \\
\text { (drywall, } \\
\text { etc.) } \\
\end{array}$ & $\begin{array}{l}\text { Same as } \\
\text { baseline }\end{array}$ & $\begin{array}{l}\text { Baseline plus: } \\
\text { Improved controls } \\
\text { from electric } \\
\text { reheat }\end{array}$ & $\begin{array}{c}\text { Baseline plus: } \\
\text { Improved control } \\
\text { from VAV; reduced } \\
\text { VOCs in new lobby } \\
\text { materials }\end{array}$ & $\begin{array}{l}\text { Bundle } 2 \text { plus } \\
\text { reduced VOCs } \\
\text { in new lobby } \\
\text { materials }\end{array}$ \\
\hline
\end{tabular}

Financial and environmental analysis was undertaken as a single process as follows. For each bundle, a conceptual design was developed and this was used to develop a simplified energy model to predict ongoing energy costs and associated GHG emissions, as well as to develop the construction cost estimate and duration estimate. The outputs of this analysis were used to predict operational (energy and maintenance) costs. Income (rent) was estimated based on lease conditions in comparable buildings within the immediate area, such as typical rental rates, lease-free period, and potential green premium rents (limited to Class A buildings capable of meeting the LEED ${ }^{\circledR}$ EB:O\&M pre-requisites). Finally, the discount rate used was the minimum internal rate of return acceptable to the property owner. To evaluate the drivers in the qualitative, wellness, and risk mitigation categories, the performance of each bundle with respect to each individual driver was evaluated on a Likert Scale from -3 (very poor performance) to +3 (extremely good performance/best practice). These performance values are then used to calculate an overall performance as presented for wellness in Equation (4). For each category, each performance rating is multiplied by the priority weighting for the driver, and summed to obtain $Q_{i}$, $W_{i}$ and $R_{i}$, respectively. While each driver is not truly independent of the others, the simplification of considering each driver individually is expedient and necessary for ease of use of this methodology. The evaluation and model development to address relationships between individual drivers this model warrants future research. 


\subsection{Results}

Table 5 presents the financial and risk performance results. The degree to which qualitative factors and wellness-promoting features were integrated in these bundles were calculated for each bundle in Tables 6 and 7, respectively.

Table 5. Financial and risk performance.

\begin{tabular}{cccccc}
\hline Factor & Baseline & Bundle 1 & Bundle 2 & Bundle 3 & Bundle 4 \\
\hline$\Delta N P V_{i} / \Delta N P V_{\max }$ & 0 & 0.17 & 0.66 & 0.58 & 1.00 \\
$R_{i} / R_{i \max }$ & 0.76 & 1.00 & 0.88 & 1.00 & 0.62 \\
\hline
\end{tabular}

Table 6. Qualitative factor evaluation.

\begin{tabular}{ccccccc}
\hline Qualitative Driver & $\boldsymbol{W}_{\boldsymbol{p q}}$ & Baseline & Bundle 1 & Bundle 2 & Bundle 3 & Bundle 4 \\
\hline Disruption \& Potential Vacancy Period & 1 & 0 & 2 & 2 & 3 & 3 \\
Occupancy Density & 0.5 & 0 & 3 & 3 & 3 & 2 \\
Performance Prediction Accuracy & 0.5 & 0 & 3 & 2 & 2 & 2 \\
$\quad$ Landlord Approvals & 1 & 0 & 2 & 2 & 3 & 3 \\
Remaining Life of Building/ & 0.5 & 2 & 2 & 2 & 2 & 2 \\
$\quad$ Major Systems & & & & & & \\
Compliance with Market Standards & 0.8 & 3 & 3 & 3 & 3 & 3 \\
$\quad$ (OBC etc.) & - & 0.57 & 1.73 & 1.65 & 1.98 & 1.90 \\
Qualitative Experience Score $\left(Q_{i}\right)$ & - & 0.29 & 0.87 & 0.83 & 1.00 & 0.96 \\
$\quad Q_{i} / Q_{i m a x}$ & & & & & &
\end{tabular}

Table 7. Wellness enabler potential evaluation.

\begin{tabular}{ccccccc}
\hline Wellness Enabler & $\boldsymbol{W}_{\boldsymbol{p} w}$ & Baseline & Bundle 1 & Bundle 2 & Bundle 3 & Bundle 4 \\
\hline Comfort-user control & 0.1 & 0 & 0 & 0 & 0 & 0 \\
Comfort-thermal comfort & 1.0 & -1 & 2 & 1 & 3 & 1 \\
Comfort-indoor noise level & 0.5 & 0 & -1 & 1 & 3 & 1 \\
Daylight-access to natural light & 0.3 & -1 & 0 & 0 & 0 & 0 \\
Daylight-access to views & 0.3 & 0 & 0 & 0 & 0 & 0 \\
Air Effects-improved air & 0.3 & 0 & 0 & 2 & 2 & 2 \\
distribution & & 1 & 1 & 1 & 3 & 3 \\
Air Effects-low-VOC materials & 0.3 & -1.0 & 1.8 & 2.4 & 6.0 & 3.0 \\
Wellness Enabler Score $\left(W_{i}\right)$ & - & -0.17 & 0.30 & 0.40 & 1.00 & 0.50 \\
$W_{i} / W_{\text {imax }}$ & - & & & & &
\end{tabular}

These tables indicate the highest financial performance for Bundle 4, and highest risk, wellness and qualitative performance for Bundle 3. Table 8 presents the holistic scores for these bundles in three hypothetical scenarios: (1) all factors rated equally; (2) risk weighted most heavily, followed by cost, then qualitative and wellness $\left(W_{R}=0.6, W_{C}=0.2, W_{Q}=W_{W}=0.1\right)$; and (3) cost weighted most heavily, followed by risk, then qualitative and wellness $\left(W_{R}=0.2, W_{C}=0.6, W_{Q}=W_{W}=0.1\right)$. The preferred bundle for each weighting factor combination has been indicated with bold text. 
Table 8. Holistic Evaluation.

\begin{tabular}{cccccc}
\hline Weighting Factors & Baseline & Bundle 1 & Bundle 2 & Bundle 3 & Bundle 4 \\
\hline$W_{C}=0.6, W_{R}=0.2, W_{Q}=W_{W}=0.1$ & 0.16 & 0.42 & 0.70 & 0.75 & $\mathbf{0 . 8 7}$ \\
$W_{C}=0.2, W_{R}=0.6, W_{Q}=W_{W}=0.1$ & 0.47 & 0.75 & 0.78 & $\mathbf{0 . 9 2}$ & 0.72 \\
$W_{C}=W_{R}=W_{Q}=W_{W}=0.25$ & 0.22 & 0.59 & 0.69 & $\mathbf{0 . 9 0}$ & 0.77 \\
\hline
\end{tabular}

Note: * bold text indicates the best-performing bundle for a given combination of weighting factors

\subsection{Project Recommendations and Conclusions}

In the historical project, risk and qualitative/wellness effects were considered to be the most important, leading to the recommendation and stakeholder acceptance of Bundle 3, which formed the basis for the renovation and resulted in rapid leasing of this property. This example demonstrates the effectiveness of this framework to balance multiple stakeholder priorities and allow for a customized and optimized evaluation of potential retrofits.

\section{Recommendations and Conclusions}

Energy conservation measures provide direct, quantifiable savings when incorporated into building retrofits and have become a standard component of renovations; however wellness enabling by these retrofits can achieve a far higher economic value to the occupier than the energy conservation measures themselves when productivity is considered. Given that the ratio of salaries to energy costs borne by the average business are often on the order of 100:1 [1], a 1\%-2\% improvement in productivity will more than exceed the total energy cost. Where poor conditions exist, reducing the corresponding decreased productivity is quantifiable and well-documented in the literature.

While many wellness enablers are also beneficial to improving energy efficiency, for example improved daylighting, others such as increased outdoor air provision are associated with increased load. In buildings where there are few to no complaints regarding air quality and temperature, caution is recommended in relying on any productivity improvement to offset costs associated with the increased load, because the majority of studies compared good vs. poor conditions, rather than good vs. better. Within the context of building retrofits, however, other energy savings will offset these increased operational costs and while the maximum possible energy savings will not be achieved, the potential increase in productivity justifies this type of intervention as part of equipment replacement.

The proposed framework aligns wellness enablers with complementary energy conservation measures and provides a methodology to evaluate retrofits not only from an economic perspective, but also including a range of environmental, risk, wellness and occupant experience drivers. By using this approach, renovations can be evaluated holistically to meet the specific priorities of the stakeholder group and thus promote healthy work environments while achieving simultaneous energy savings.

Limitations to this current research warranting further exploration are a lack of comprehensive assessments on the economic benefits of specific wellness-promoting building strategies, particularly within the commercial office context, and of their interactions. Further exploration of this theme in other contexts is also warranted to reflect the differing nature of "productivity" across sectors within specific contexts (particularly commercial offices), and their interaction. The WELL Building Standard is also 
in its very early stages of adoption and is expected to evolve over time, as emerging research in public health and productivity leads to the identification of new wellness enablers and strategies.

\section{Acknowledgements}

The authors would like to thank Nathan Stodola from the International WELL Building Institute for early access to the WELL ${ }^{\circledR}$ building standard to facilitate development of this paper.

\section{Author Contributions}

Chris Jofeh conceived of the wellness expansion to the existing model; J. J. McArthur derived the revised mathematical approach presented, wrote this paper and performed the literature review; Ann-Marie Aguilar provided insight on the WELL Building Standard and worked with the other authors to evaluate these from a wellness perspective; and all three authors worked together to develop the paper's scope.

\section{Conflicts of Interest}

The authors declare no conflict of interest.

\section{References}

1. Majesky, O.; Dooney, J.; Williams, S. Salaries as a Percentage of Operating Expense. Available online: http://www.shrm.org/research/articles/articles/pages/metricofthemonthsalariesas percentageofoperatingexpense.aspx (accessed on 23 October 2014).

2. Feige, A.; Wallbaum, H.; Janser, M.; Windlinger, L. Impact of sustainable office buildings on occupant's comfort and productivity. J. Corp. Real Estate 2013, 15, 7-34.

3. Wyon, D.P. The effects of indoor air quality on performance and productivity. Indoor Air 2004, 14, 92-101.

4. International Well Building Institute and Green Building Certification Institute Announce New Collaboration. Available online: http://www.usgbc.org/articles/international-well-building-instituteand-green-building-certification-institute-announce-n (accessed on 8 June 2015).

5. International Well Building Institute. WELL ${ }^{\circledR}$ Building Standard Executive Summary. Available online: http://nowinteractive.net/delos-downloads/WBS-Executive\%20Summary-Apr2014.pdf (accessed on 8 June 2015).

6. Eichholtz, P.; Kok, N.; Yonder, E. Portfolio greenness and the financial performance of REITs. J. Int. Money Financ. 2012, 31, 1911-1929.

7. Kok, N.; McGraw, M.; Quigley, J.M. The Diffusion of energy efficiency in building. Am. Econ. Rev. 2011, 101, 77-82.

8. Fuerst, F. Building momentum: An analysis of investment trends in LEED and energy star-certified properties. J Retail Leisure Property 2009, 8, 285-297.

9. Qiu, Y.; Tiwari, A.; Wang, Y.D. The diffusion of voluntary green building certification: A spatial approach. Energy Effic. 2015, 8, 449-471. 
10. Andaloro, A.P.F.; Salomone, R.; Ioppolo, G.; Andaloro, L. Energy certification of buildings: A comparative analysis of progress towards implementation in European countries. Energy Policy 2010, 38, 5840-5866.

11. Breslau, B.; Fowles, R.H. Sustainability Perspectives and Trends in Corporate Real Estate. Available online: http://www.joneslanglasalle.com/ResearchLevel1/Global_Trends_in_Sustainable_Real_Estate_-_Feb_2008_EN.pdf (accessed on 4 September 2015).

12. Cajias, M.; Paizolo, D. Green performs better: Energy efficiency and financial return on buildings. J. Corp. Real. Estate 2013, 15, 53-72.

13. Rajagopalan, P.; Leung, T.C.Y. Progress on building energy labelling techniques. Adv. Build. Energy Res. 2012, 6, 61-80.

14. Balaras. C.A.; Dascalaki, E.G.; Droutsa, K.G.; Kontoyiannidis, S.; Guruz, R.; Gudnason, G. Energy and other key performance indicators for buildings-examples for hellenic buildings. Glob. J. Energy Tech. Res. Updates 2014, 1, 71-89.

15. Energy Performance Certificates in Buildings and Their Impact on Transaction Prices and Rents in Selected EU Countries. Available online: https://ec.europa.eu/energy/sites/ener/files/documents/ 20130619-energy_performance_certificates_in_buildings.pdf (accessed on 4 September 2015).

16. The Dollars and Sense of Green Buildings. Available online: http://www.gbca.org.au/resou rces/dollars-and-sense-of-green-buildings-2006-building-the-business-case-for-green-c/1002.htm (accessed on 4 September 2015).

17. Fuerst, F.; McAllister, P. Eco-labeling in commercial office markets: Do LEED and energy star offices obtain multiple premiums? Eco. Econ., 2011, 70, 1220-1230.

18. Fuerst, F.; McAllister, P. The impact of energy performance certificates on the rental and capital values of commercial property assets. Energy Policy 2011, 39, 6608-6614.

19. Parkinson, A.T.; Cooke, A.J. Market responses to the sustainability and energy performance of commercial property. In Sustainability in Energy and Buildings; M'Sirdi, N., Namaane, A., Howlett, R.J., Jain, L.C., Eds.; Springer Berlin Heidelberg: Berlin, Germany, 2012; pp. 85-97.

20. Leopoldsberger, G.; Bienert, S.; Brunauer, W.; Bobsin, K.; Schützenhofer, C. Energising property valuation: Putting a value on energy-efficient buildings. Int. Apprais. 2011, 79, 115-125.

21. Kok, N.; Jennen, M. The impact of energy labels and accessibility on office rents. Energy Policy 2012, 46, 489-497.

22. Remøy, H.; van der Voordt, T.J.M. Priorities in accommodating office user preferences: Impact on office users decision to stay or go. J. Corp. Real. Estate 2014, 16, 140-154.

23. Bonde, M. Difficulties in changing existing leases-one explanation of the "energy paradox". J. Corp. Real. Estate 2012, 14, 63-76.

24. Morrissey, J.; Dunphy, N.; MacSweeney, R. Energy efficiency in commercial buildings: Capturing added-value of retrofit. J. Prop. Invest. Fin. 2014, 32, 396-414.

25. Finnegan, M.J.; Pickering, C.A.; Burge, P.S. The sick building syndrome: Prevalence studies. British Med. J. 1984, 289, 1573-1575.

26. Wargocki, P.; Wyon, D.P.; Sundell, J.; Clausen, G.; Fanger, P.O. The effects of outdoor air supply rate in an office on perceived air quality, sick building syndrome (SBS) symptoms and productivity. Indoor Air 2000, 10, 222-236. 
27. Singh, J. Impact of indoor air pollution on health, comfort and productivity of the occupants. Aerobiologia 1996, 12, 121-127.

28. Heschong, L. Daylighting In Schools: An Investigation into The Relationship between Daylighting and Human Performance. Available online: http://eric.ed.gov/?id=ED444337 (accessed on 4 September 2015).

29. Choi, J.H.; Beltran, L.O.; Kim, H.S. Impacts of indoor daylight environments on patient average length of stay (ALOS) in a healthcare facility. Build. Environ. 2012, 50, 65-75.

30. A Staff and Patient Environment Calibration Toolkit (ASPECT). Available online: http:// webarchive.nationalarchives.gov.uk/20130107105354/http://www.dh.gov.uk/prod_consum_dh/gr oups/dh_digitalassets/@dh/@en/documents/digitalasset/dh_082081.pdf (accessed on 29 September 2015).

31. Achieving Excellence Design Evaluation Toolkit (AEDET). Available online: http://webarhive.nationalarchives.gov.uk/20130107105354/http:/www.dh.gov.uk/en/Publicationsandst atistics/Publications/PublicationsPolicyAndGuidance/DH_082089 (accessed on 29 September 2015).

32. Reid, D.N.; Armstrong, D.; Kane, M. The role of hospital design in the recruitment, retention and performance of NHS nurses in England. Available online: http://webarchive.nation alarchives.gov.uk/20110118095356/cabe.org.uk/files/the-role-of-hospital-design-appendices.Pdf (accessed on 4 September 2015).

33. Building Use Studies Ltd. BUS Methodology. Available online: http://www.busmethodology.org (accessed on 9 October 2014).

34. Kaklauskas, A.; Zavadskas, E. K.; Raslanas, S. Multivariant design and multiple criteria analysis of building refurbishments. Energy Build. 2005, 37, 361-372.

35. Stephan, K.; Menassa, C. Modeling the effect of building stakeholder interactions on value perception of sustainable retrofits. J. Comput. Civ. Eng. 2014, 29, doi:10.1061/(ASCE)CP.19435487.0000409.

36. De Brucker, K.; Macharis, C.; Verbeke, A. Multi-criteria analysis and the resolution of sustainable development dilemmas: A stakeholder management approach. Eur. J. Op. Res. 2013, 224, 122-131.

37. McArthur, J.J.; Jofeh, C.G.H. Strategic retrofit investment from the portfolio to the building scale: A framework for identification and evaluation of potential retrofits. In Proceedings of Procedural Engineering International Conference on Sustainable Design, Engineering and Construction, Chicago, IL, USA, 10-13 May 2015.

38. Juslén, H.T.; Wouters, M.C.H.M.; Tenner, A.D. Lighting level and productivity: A field study in the electronics industry .Ergonomics 2007, 50, 615-624.

(C) 2015 by the authors; licensee MDPI, Basel, Switzerland. This article is an open access article distributed under the terms and conditions of the Creative Commons Attribution license (http://creativecommons.org/licenses/by/4.0/). 